\title{
Influence of gamma irradiation on the colour parameters of dry smoked shrimps (Penaeus notialis)
}

\author{
${ }^{1}$ Akuamoah, F., ${ }^{2}$ Odamtten, G.T. and ${ }^{3 *}$ Kortei, N.K. \\ ${ }^{1}$ Applied Radiation Biology Centre, Radiological and Medical Sciences Research Institute, Ghana Atomic \\ Energy Commission, P. O. Box AE 1, Atomic-Accra, Ghana \\ ${ }^{2}$ Department of Plant and Environmental Biology, College of Basic and Applied Sciences, University of \\ Ghana, P. O. Box LG 55, Legon, Ghana \\ ${ }^{3}$ Department of Nutrition and Dietetics, School of Allied Health Sciences, University of Health and Allied \\ Sciences, PMB 31, Ho, Ghana
}

\begin{abstract}
Article history:
Received: 7 November 2017

Received in revised form: 5

January 2018

Accepted: 6 January 2018

Available Online: 27 April 2018
\end{abstract}

Keywords:

Shrimps,

Colour,

Gamma radiation,

Waterbodies

DOI:

https://doi.org/10.26656/fr.2017.2(4).0271

\begin{abstract}
Shrimp meat is one of the safest forms of muscle protein consumed in Ghana and in the world at large. Shrimps obtained from three different sources were smoke-dried to a moisture content of $15 \%$ and exposed to ionizing radiations from a Cobalt 60 source (Hungary, SLL 515) at doses of 0 (control), 4, 8 and $10 \mathrm{kGy}$ at a dose rate of $2.17 \mathrm{kGy} /$ hour in air. The effect of gamma radiation on colour was monitored before and after gamma irradiation. The colour parameters for the samples and colour change due to gamma irradiation were in the ranges 31.87 - 33.34 ( $\mathrm{L}^{*}$ - whiteness/blackness), 8.19 8.97 ( $\mathrm{a}^{*}$ - redness/greenness), $18.51-20.22\left(\mathrm{~b}^{*}\right.$ - yellowness/blueness), $20.35-22.12$ (C - chroma), 65.44 - 66.49 ( $\mathrm{H}^{\mathrm{o}}$ - Hue angle) and 23.53 - 105.88 (B.I - Browning Index). These values were also used for calculation of the total colour change $(\Delta \mathrm{E})$, chroma change $(\Delta \mathrm{C})$, hue angle change $(\Delta \mathrm{H})$ and browning index change $(\Delta \mathrm{B}$.I). There were significant differences $(\mathrm{P}<0.05)$ for $\mathrm{L}^{*}, \mathrm{a}^{*}, \mathrm{~b}^{*}$, chroma, hue angle, browning index and overall colour change of shrimps after exposure to gamma radiations. Gamma radiation proved to be an effective preservative method for extension of shelf life of shrimp as neither no peculiar nor recorded.
\end{abstract}

\section{Introduction}

The colour attribute of a product, is notably important to the consumer as a quality criterion since consumers associate it with freshness (Campbell et al., 2004). Discoloured products are most often not attractive and this raises concerns about its wholesomeness and so producers always endeavor to prevent products with defective colorations from reaching the market (Abdullah et al., 2004; Hatcher et al., 2004) because when they don't, their prices are significantly affected (Cui et al., 2004) or are rejected entirely by the consumer (Waliszewski et al., 1999).

The importance of shrimp in human diets cannot be overemphasized. Shrimp is an essential source of protein; $113 \mathrm{~g}$ of shrimp a day provides the human body with $24 \mathrm{~g}$ of protein which represents $47.4 \%$ of the daily needs of the human protein. About $20 \mathrm{~g}$ of protein is contained in three ounces of baked or broiled shrimp which provides just a few grams less than that a 3 -ounce chicken breast. Each huge shrimp provides about $3 \mathrm{~g}$ and contains very little fat and carbohydrate (Sass, 2014). Hence, shrimp could be considered as a supplement for meat protein. In Ghana and most parts of the world, drying remains one of the best options of preprocessing this seafood and it is one of the oldest means of food preservation (Bala et al., 2009; Kortei et al., 2016). After drying, they are used (in whole or powdered form) in soups and sauces as a major protein source and for their delectable flavor (Akonor et al., 2016) and they are also used in preparing some local dishes (apapransa etc).

To further enhance product quality and prolong the shelf life of these shrimps, other pretreatments such as gamma irradiation have been employed after food dehydration (Wang and Chao, 2002; Yu and Wang, 2005). Food processing by employing radiation is well established as a physical, non-thermal mode of food preservation (cold-pasteurization) which processes foods at or nearly at ambient temperature. Irradiation of food 
products nonetheless, causes a minimal modification in the flavor, color, nutrients, taste, and other quality attributes of food. Bhat and Sridhar (2008) and Mexis et al. (2009) however reiterated that, the degrees of modification (whether in taste, flavor, color, nutrients etc.) might vary depending on factors such as the basic raw material used, irradiation dose delivered, and on the type of radiation source employed (gamma, X-ray, UV, electron beam).

An objective means of measuring the colour of a product is by instrumental analysis since there are some limitations with subjective human sensory analysis as influenced by gamma irradiation. The objective of this study was to assess the influence of gamma radiation on the colour parameters of smoke-dried shrimps kept in polypropylene packs and stored at room temperature.

\section{Materials and methods}

\subsection{Shrimp species used}

Dehydrated-smoked shrimps (Penaeus notialis) were purchased from three different areas, and sources. The sources were Sea, Lagoon, and River. These areas were "Faana", "Tsokome" and "Bortiano" respectively which are located in the coastal areas of Kasoa, a suburb of the Central region of Ghana.

\subsection{Irradiation of shrimp materials}

Thirty (30) grams of smoke-dried shrimps were packed into high-density polypropylene containers and irradiated at doses of $0,2,4$ and $8 \mathrm{kGy}$ at a dose rate of $1.7 \mathrm{kGy}$ per hour in air from a cobalt 60 source (SLL 515 , Hungary) of strength $26 \mathrm{Kci}$. Radiations absorbed were confirmed using the ethanol-chlorobenzene (ECB) dosimetry system at the Radiation Technology Centre of the Ghana Atomic Energy Commission, Accra, Ghana.

\subsection{Determination of colour}

The CR-310 Chroma meter (Minolta Camera Co., Osaka, Japan), operating in the Commission Internationale D'Eclairage (CIE) system, where $\mathrm{L}^{*}$ for lightness, $a^{*}$ for redness (red \pm green) and $b^{*}$ for yellowness (yellow \pm blue) was used to measure the colour $\left(L^{*} a^{*} b^{*}\right)$ of the shrimp samples. The colorimeter was standardized using a white tile (Illuminant D65) and the measurements were made on the surface of dehydrated-smoked shrimp. The CR-310 consists of a data processor and a 50-mm-diameter measuring head that covers the specimen and excludes all external light. The head uses wide-area illumination, $0^{\circ}$ viewing angle, and a relatively large measuring area. The large area improves accuracy on textured surfaces. A pulsed, xenon arc lamp mounted inside a mixing chamber emits diffuse, uniform light over the measuring area. Light reflected from the specimen is collected by an opticalfiber cable for colour analysis (Chroma Meter CR-310 Instruction Manual).

The color (L* $\left.a^{*} b^{*}\right)$ of both irradiated and unirradiated samples was measured by placing the measuring head of the CR-310 colorimeter carefully into the dense polypropylene bowls and the colour measurement taken. The samples were closely packed in order to minimize space and reduce error. Measurements were done immediately after irradiation in triplicates and reported with means and standard deviations.

The hue angle (Ho) which describes the relative amounts of redness and yellowness in a sample is interpreted as $0^{\circ} / 360^{\circ}$ for red/magenta, $90^{\circ}$ for yellow, $180^{\circ}$ for green and $270^{\circ}$ for blue or purple, or intermediary colors between adjacent pairs of these basic colors (Schnell et al., 2005; Pedisic et al., 2009). A minimum hue value expressed a redder product while a maximum expressed a bluer or purple product. Metric Chroma (C) measures color intensity or saturation. Both Hue angle and chroma were calculated from $a^{*}$ and $b^{*}$ values according to the formulae prescribed by Wrolstad and Smith (2010) as follows:

$$
\begin{aligned}
& \text { Hue angle }\left({ }^{\circ}\right)=\tan ^{-1}\left(b^{*} / a^{*}\right) \\
& \text { Chroma }=\sqrt{ }\left(a^{* 2}+b^{* 2}\right)
\end{aligned}
$$

The color difference if pretreated samples, $\Delta \mathrm{E}$, was calculated in relation to the control sample (Saricoban and Yilmaz, 2010) as follows;

$$
\Delta \mathrm{E}=\left[\left(\mathrm{L}_{\mathrm{o}}-\mathrm{L}^{*}\right)^{2}+\left(\mathrm{a}_{\mathrm{o}}-\mathrm{a}^{*}\right)^{2}+\left(\mathrm{b}_{\mathrm{o}}-\mathrm{b}^{*}\right)^{2}\right]^{1 / 2}
$$

Where:

$\mathrm{L}_{\mathrm{o}}, \mathrm{a}_{\mathrm{o}}$ and $\mathrm{b}_{\mathrm{o}}$ are values for initial.

$L^{*}, a^{*}$, and $b^{*}$ are values for the final/pretreated sample.

The Browning index (BI) according to Lopez-Malo (1998) represents the purity of brown colour and is considered as an important parameter associated with browning. The browning index calculations were done using $\mathrm{L}^{*}, \mathrm{a}^{*}, \mathrm{~b}^{*}$ according to methods prescribed by Mohammadi et al. (2008) and Kortei et al. (2015) as follows:

$$
\text { Browning Index (B. I. ) }=\frac{[100(x-0.31)]}{0.17}
$$

Where:

$$
\mathrm{X}=\frac{\left(\mathrm{a}^{*}+1.75 \mathrm{~L}^{*}\right)}{\left(5.645 \mathrm{~L}^{*}+\mathrm{a}^{*}-3.012 \mathrm{~b}^{*}\right)}
$$

$$
\Delta \mathrm{H}=\mathrm{H}_{\mathrm{o}} \text { control }-\mathrm{H}_{\mathrm{o}} \text { sample }
$$


$\Delta \mathrm{L}=\mathrm{L} *$ control $-\mathrm{L}^{*}$ sample

$\Delta$ Chroma $=$ Chroma control - Chroma sample (7)

\subsection{Statistical analysis}

Data of color parameters were recorded in triplicate. Results are expressed as mean values and standard deviation (SD). One-way analyses of variance were used to analyse data obtained from the study and Duncan's multiple range test with $p=0.05$ was used to determine significant differences between variables. The analysis was carried out using SPSS 23 (Chicago, IL, USA).

\section{Results and discussion}

The market value of shrimp is dependent on the visual appearance of their body color (Yanar et al., 2004; Kortei et al., 2015). Results of the colour parameters before and after gamma irradiation are presented in Table 1. Whiteness $\left(\mathrm{L}^{*}\right)$ values ranged between 31.87 33.34. There was a general trend of decreasing whiteness with increasing radiation dose. Yellow/ blue $\left(b^{*}\right)$ values ranged between 18.51-20.22. There were no significant differences $\left(p^{3} 0.05\right)$ in the $L^{*}$ (brightness or whiteness) and $b^{*}$ (yellowness) values, between the control and the irradiated samples (Table 1). According to Aktas et al. (2011), decreasing of the $L^{*}$ values in these applications supported the decreasing of $b^{*}$ values namely occurring of slight browning which is attributed to nonenzymatic browning (Kotwaliwale et al., 2010). Whiteness is known to be affected by physicochemical properties and pretreatments (Matser et al., 2000).

Wang et al. (2010), found that $\mathrm{L}^{*}$ value increased as radiation dose increased while $\mathrm{a}^{*}$ value decreased as radiation dose increased up to $9 \mathrm{kGy}$ in fried shrimp. This contradicts the present findings. Nonetheless, results obtained agreed with findings of Kortei et al. (2015) who worked on the effect of gamma radiation, packaging, and storage on the colour parameters of dried oyster mushrooms.

Red/green $\left(\mathrm{a}^{*}\right)$ values of the shrimps ranged from 8.19 - 8.97. There was an observed general decrease in red/green $\left(\mathrm{a}^{*}\right)$ values with increasing gamma radiation doses. Analysis of variance (ANOVA) showed significant $(p<0.05)$ differences among the other treatments. Astaxanthin, a carotenoid pigment is responsible for the red-orange tissue pigmentation of shrimp meat (Yanar et al., 2004). Chemical changes in raw meat such as protein denaturation, oxidation, hydrolysis, changes in $\mathrm{pH}$, and enzyme action are also significant factors affecting the colour of raw meat (Reid, 1999).

Results of Metric Chroma (c), Hue angle and Browning index values ranged from 20.35 - 22.12, 65.44 - 66.49 and 23.53 - 105.88 respectively. The chroma value, calculated using Equation (2), indicated the degree of saturation of colour and was proportional to the strength of the colour. The hue angle range was within the $90^{\circ}$ region which suggests an apparent reddish yellow color (Pedisic et al., 2009; Kortei et al., 2015). The chroma values were changed by the processing variables, which indicated instability of orange - yellow colour in shrimps due to processing variables. There was a general decrease in (C) values. Gonçalves et al. (2007) suggested that lower $(\mathrm{C})$ value indicates an increase in the tonality of the sample's colour. This observation was in disagreement with work of Viskelis et al. (2011) who reported an increase in metric chroma values of apples during storage. Development of redness on exposure of shrimp meat to heat and/or gamma radiation is as a result of the release of astaxanthin when carotenoproteins breakdown during protein denaturation (Niamnuy et al., 2007; Akonor et al., 2016).

Darkening may have occurred because of Maillard browning reactions which took place during drying which gives an indication of a high rate of occurrence of enzymatic browning for pretreated samples (Akonor et al., 2016). Furthermore, only $\mathrm{L}^{*}$ and $\mathrm{a}^{*}$ values seemed to be related to the extent of browning, as already described by other authors (Sapers and Douglas, 1987; Snoeck et al., 2011). As found by Cantos et al. (2002), the best indicator of browning in fresh cut potato was the $\mathrm{L}^{*}$ parameter (lightness factor). A decrease in $L^{*}$ value and an increase in $\mathrm{a}^{*}$ value as indicators of browning have been reported by several authors (Mastrocola and Lerici, 1991; Monsalve-Gonzalez et al., 1993). There were no significant $(\mathrm{p}>0.05)$ changes in $\mathrm{b}^{*}$ parameter (Table 1$)$. The extent of these reactions in dried and gamma irradiated samples of 0,8 and $10 \mathrm{kGy}$ was more pronounced and resulted in a darker shrimp meat compared to the $4 \mathrm{kGy}$ which had a lower Browning Index (B.I) and suggests a slow rate of enzymatic

Table 1. Influence of gamma radiation on colour parameters of shrimps

\begin{tabular}{ccccccc}
\hline Dose $(\mathrm{kGy})$ & $\mathrm{L}^{*}$ & $\mathrm{a}^{*}$ & $\mathrm{~b}^{*}$ & Chroma & Hue & B.I \\
\hline 0 & $33.34 \pm 0.74^{\mathrm{a}}$ & $8.97 \pm 0.32^{\mathrm{b}}$ & $20.22 \pm 0.79^{\mathrm{a}}$ & 22.12 & 66.07 & 105.88 \\
4 & $31.87 \pm 0.74^{\mathrm{a}}$ & $8.19 \pm 0.32^{\mathrm{a}}$ & $18.71 \pm 0.79^{\mathrm{a}}$ & 20.42 & 66.36 & 23.53 \\
8 & $33.24 \pm 0.74^{\mathrm{a}}$ & $8.49 \pm 0.32^{\mathrm{ab}}$ & $18.71 \pm 0.79^{\mathrm{a}}$ & 21.29 & 66.49 & 105.88 \\
10 & $32.18 \pm 0.74^{\mathrm{a}}$ & $8.46 \pm 0.32^{\mathrm{ab}}$ & $18.51 \pm 0.79^{\mathrm{a}}$ & 20.35 & 65.44 & 100.00 \\
\hline
\end{tabular}


browning of astaxanthins (Kortei et al., 2015). Results agreed with previous work of Akonor et al. (2016) who reported colour values within range as they investigated the drying characteristics, physical and nutritional properties of shrimp meat as affected by different traditional drying techniques in Ghana.

Change in Metric Chroma and Hue angle values (0.83 - 0.71, - $0.29-1.77$ respectively) were marginal due to gamma radiation pretreatment. The total colour difference $(\Delta \mathrm{E})$ indicates the magnitude of the difference between locations in the CIE $L^{*} a^{*} b^{*}$ colour system (Table 2) and it is also a colorimetric parameter extensively used to characterize the variation of colours depending on the processing conditions (Maskan, 2001). Higher $\Delta \mathrm{E}$ results indicate a greater relative change in colour compared to the shrimp meat's original colour (Saricoban and Yilmaz, 2010; Jouki and Yazdi, 2014).

Table 2. Total colour change due to gamma irradiation

\begin{tabular}{ccccccc}
\hline $\begin{array}{c}\text { Dose } \\
(\mathrm{kGy})\end{array}$ & $\Delta \mathrm{L}^{*}$ & $\Delta \mathrm{a}^{*}$ & $\Delta \mathrm{b}^{*}$ & $\Delta$ Chroma & $\Delta$ Hue & $\Delta \mathrm{E}$ \\
\hline 0 & - & - & - & - & - & - \\
4 & 1.47 & 0.78 & 1.51 & 1.7 & -0.29 & 2.26 \\
8 & 0.1 & 0.48 & 0.7 & 0.83 & -0.42 & 0.84 \\
10 & 1.16 & 1.16 & 0.51 & 1.71 & 1.77 & 2.13 \\
\hline
\end{tabular}

Although low values of $\Delta \mathrm{E}$ which ranged between $0.84-2.26$ were recorded in this present study as the overall color difference, there was an observed decrement in $\Delta \mathrm{E}$ which showed that increasing gamma radiation doses decreased the total change in the colour of meat shrimp. The main cause of colour change during drying is enzymatic and non-enzymatic browning reactions (Maillard reaction), which depend on temperature as well as the duration of pretreatment (Chua et al., 2002; Giri et al., 2013). Furthermore, it could be due to the absence of water in the capillary voids of the dried smoked shrimps which usually transport the enzymes to catalyze the oxidation of carotenoid substrates into carotenoproteins which then undergo subsequent reactions leading to the formation of astaxanthins (Akonor et al., 2016).

Results obtained agreed with $\Delta \mathrm{E}$ values reported by Akonor et al. (2016) as they investigated the drying characteristics, physical and nutritional properties of shrimp meat as affected by different traditional drying techniques in Ghana. Saricoban and Yilmaz (2010), reported a similar trend modelling the effects of processing factors on the changes in colour parameters of cooked meatballs using response surface methodology in Turkey.

\section{Conclusion}

Although the presented data showed some significant $(\mathrm{P}<0.05)$ effect on some colour parameters due to the application of low dose gamma radiation, there were no extraordinary colors observed. The local food industry, retailers and farmers could adopt this technology to improve the hygienic quality and extend shelf-life of fresh and dried shrimps to enhance their competitiveness in domestic and export markets.

\section{Acknowledgements}

We are grateful to all laboratory technicians at the Food Science Laboratory of the Ghana Atomic Energy Commission, Kwabenya, Accra. Messers S.N.Y. Annan, J.N.O. Armah, SWNO Mills and S.A. Acquah of the Radiation Technology Center, Ghana Atomic Energy Commission (G.A.E.C), Kwabenya, Accra carried out the irradiation process.

\section{References}

Abdullah, M.Z., Guan, L.C., Lim, K.C. and Karim, A.A. (2004). The applications of computer vision and tomographic radar imaging for assessing physical properties of food. Journal of Food Engineering, 61, 125-135. https://doi.org/10.1016/S0260-8774(03) 00194-8

Akonor, P.T., Ofori, H., Dzidzoavie, N.T. and Kortei, N.K. (2016). Drying Characteristics and Physical and Nutritional Properties of Shrimp Meat as Affected by Different Traditional Drying Techniques. International Journal of Food Science, 2016, Article ID: $7879097 . \quad \mathrm{http}: / /$ dx.doi.org/10.1155/2016/7879097

Aktas, T., Hasturk Sahin, F., Orak, H. and Ulger, P. (2011). Influence of pretreatments and different drying methods on color parameters and lycopene content of dried tomato. Bulgarian Journal of Agricultural Science, 17(6), 867- 881.

Bala, B.K., Morshed, M.A. and Rahman, M.F. (2009). Solar drying of mushroom using solar tunnel dryer. International Solar Food Processing Conference, 111.

Bhat, R. and Sridhar, K.R. (2008). Nutritional quality evaluation of electron beam irradiated (Nelumbo nucifera) seeds. Food Chemistry, 107, 174-184. https://doi.org/10.1016/j.foodchem.2007.08.002

Campbell, B.L., Nelson, R.G., Ebel, C.E., Dozier, W.A., Adrian, J.L. and Hockema, B.R. (2004). Fruit quality characteristics that affect consumer preferences for satsuma mandarins. Horticulture Science, 39(7), 1664-1666. 
Cantos, E., Tudela, J.A., Gil, M.I. and Espín, J.C. (2002). Phenolic compounds and related enzymes are not rate-limiting in browning development of fresh-cut potatoes, Journal of Agricultural and Food Chemistry, 50(10), 3015-3023. https:// doi.org/10.1021/jf0116350

Cui, Z.W., Xu, S.Y. and Sun, D.W. (2004). Sun effect of microwave- vacuum drying on the carotenoids retention of carrot slices and chlorophyll retention of Chinese chive leaves. Dry Technology, 22(3), 563575. https://doi.org/10.1081/DRT-120030001

Giri, S.K. and Prasad, S. (2013). Quality Characteristics of Microwave- Vacuum Dried Button Mushrooms (Agaricus Bisporus). Octa Journal of Bioscience, 1 (1), 24-31.

Gonçalves, B., Silva, A.P., Moutinho-Pereira, J., Bacelar, E., Rosa, E. and Meyer, S.A. (2007). Effect of ripeness and postharvest storage on the evolution of colour and anthocyanins in cherries (Prunus avium L.). Food Chemistry, 103, 976- 984. https:// doi.org/10.1016/j.foodchem.2006.08.039

Hatcher, D.W., Symons, S.J. and Manivannan, U. (2004). Developments in the use of image analysis for the assessment of oriental noodle appearance and colour. Journal of Food Engineering, 61, 109-117. https://doi.org/10.1016/S0260-8774(03)00192-4

Jouki, M. and Yazdi, F.T. (2014). The effect of gamma irradiation and vacuum packaging upon selected quality traits of refrigerated ostrich meat. Part 2. Colour, texture and lipid oxidation properties. Animal Science Papers and Reports, 32(2), 161-171.

Kortei, N.K., Odamtten, G.T, Obodai, M, Appiah, V. and Akonor P.T. (2015). Determination of color parameters of gamma irradiated fresh and dried mushrooms during storage. Croatian Journal of Food Technology, Biotechnology and Nutrition, 10(1 -2), 66-71.

Kortei, N.K., Odamtten, G.T., Ayim-Akonor, M. and Akonor, P.T. (2016). Modeling the solar drying kinetics of gamma irradiation-pretreated oyster mushrooms (Pleurotus ostreatus). International Food Research Journal 23(1), 34-39.

Lopez-Malo, A., Palou, E., Barbosa-Canovas, G.V., Welti-Chanes, J. and Swanson, B.G. (1998). Polyphenol oxidase activity and color changes during storage of high hydrostatic pressure treated avocado puree. Food Research International, 31(8), 549-556. https://doi.org/10.1016/S0963-9969(99) 00028-9

Maskan, M. (2001). Kinetics of colour change of kiwi fruits during hot air and microwave drying. Journal of Food
Engineering, 48, 169-175. https://doi.org/10.1016/ S0260-8774(00)00154-0

Mastrocola, D. and Lerici, C.R. (1991). Colorimetric measurements of enzymatic and non-enzymatic browning in apple purees. Italian Journal of Food Science, 3(4), 218-233.

Mexis, S.F., Badeka, A.V., Chouliara, E., Riganakos, K. and Kontominas, M.G. (2009). Effect of gamma irradiation on the physicochemical and sensory properties of raw unpeeled almond kernels (Prunus dulcis). Innovation in Food Science Emerging Technology, 10, 87-92. https://doi.org/10.1016/ j.ifset.2008.09.001

Mohammadi, A., Shahin R., Zahra E.D. and Alirez K. (2008). Kinetic models for colour changes in kiwi fruit slices during hot air drying. World Journal of Agricultural Sciences, 4(3): 376-383.

Monsalve-Gonzalez, A., Barbosa-Cánovas, G.V., Cavalieri, R.P., Mcevily, A.J. and Iyengar, R. (1993). Control of browning during storage of apples slices preserved by combined methods. 4hexylresorcinol as antibrowning agent. Journal of Food Science, 58(4), 797-800. https:// doi.org/10.1111/j.1365-2621.1993.tb09361.x

Niamnuy, C., Devahastin, S. and Soponronnarit, S. (2007). Effects of process parameters on quality changes of shrimp during drying in a jet-spouted bed dryer. Journal of Food Science, 72(9), 553-563. https://doi.org/10.1111/j.1750-3841.2007.00516.x

Pedisic, S., Levaj, B., Dragovic-Uzelac, V., Skevin, D. and Skendrovic-Babo, M. (2009). Color parameters and total anthocyanins of sour cherries (Prunus cerasus L.) during ripening. Agriculturae Conspectus Scientificus, 74(3), 259-262.

Reid, D.S. (1999). Practical guide: food preservation. ASHRAE Journal, 41.

Sapers, G.M. and Douglas, F.W. (1987). Measurement of enzymatic browning at cut surfaces and in juice of raw apple and pear fruits. Journal of Food Science, 52(5), 1258-1262. https://doi.org/10.1111/j.13652621.1987.tb14057.x

Saricoban, C. and Yilmaz, M.T. (2010). Modelling the effects of processing factors on the changes in colour parameters of cooked meatballs using response surface methodology. World Applied Sciences Journal, 9(1), 14-22.

Sass, C. (2014). Retrieved on July 4, 2017 from Health website: www.health.com/nutrition/calories-inshrimp

Schnell, R.J, Ayala-Da Silva, Meerow, A.W., Winterstein, M., Cervantes, C. and Brown, J.S. (2005). Determination of color and fruit traits of half 
-sib families of mango (Magnifera indica L.). Proceedings of Florida State Horticulture Society, 118, 253-257.

Viskelis P., Sasnauskas A., Rubinskiene M., Bobinas C. and Kvikliene, N. (2011). Changes in apple fruit quality during a modified atmosphere storage. Journal of Fruit and Ornamental Plant Research, 19 (1), 155-165.

Waliszewski, K., Cortes, H.D., Pardio, V.T. and Garcia, M.A. (1999). Color parameter changes in banana slices during osmotic dehydration. Drying Technology, 17(4-5), $955 \quad$ - 960. https:// doi.org/10.1080/07373939908917583

Wang, J. and Chao, Y. (2002). Drying Characteristics of irradiated apple slices. Journal of Food Engineering, 52, 83-88. https://doi.org/10.1016/S0260-8774(01) 00090-5

Wrolstad, R.E. and Smith, D.E. (2010). Colour Analysis. In Nielson S.S. (Ed). Food Analysis, p. 575-586. New York. USA: Springer Science + Business Media

Yanar, Y., Elik, M.C. and Yanar, M. (2004). Seasonal changes in total carotenoid contents of wild marine shrimps (Penaeus semisulcatus and Metapenaeus monoceros) inhabiting the eastern Mediterranean. Food Chemistry, 88(2), 267-269. https:// doi.org/10.1016/j.foodchem.2004.01.037

Yu, Y. and Wang, J. (2005). Effect of gamma-irradiation pre-treatment on drying characteristics and qualities of rice. Radiation Physics and Chemistry, 74, 378383. https://doi.org/10.1016/ j.radphyschem.2005.02.005 